\title{
WORKMEN'S COMPENSATION AND THE MARITIME LAW
}

\author{
STANLEY MORRISON
}

The introduction of workmen's compensation legislation was an innovation in the law of master and servant. Scarcely less striking than its effects in its own field was its unanticipated influence within the field of admiralty. The passage of legislation of this type by the states led to a new and far-reaching development of the doctrine of uniformity in the maritime law of the United States. The need of uniformity was invoked in order to deny the application of the state statutes to maritime injuries, and in protecting the sea law from contamination by these new notions an utter rout was inflicted upon the adherents of the common law in the centuries-old conflict between the common law and admiralty. Since the first leading decision in Southern Pacific Co. v. Jensen, ${ }^{1}$ state workmen's compensation acts, along with the rest of state law, have had only a very limited application within the maritime field. The merits and demerits of the Jensen case have been so much discussed that further extended comment upon it is uncalled for." But other difficulties remained. It became necessary to determine the powers of Congress with respect to uniformity, and to determine just where the line of demarcation should be drawn between federal and state authority. Since these difficulties have related largely to workmen's compensation, a discussion of the applicability of such relief to maritime injuries seems timely. To trace the development of this subject since Southern Pacific Co. $v$. Jensen will be the purpose of this article.

\section{THE DEVELOPMENT OF THE DOCTRINE OF UNIFORMITY}

In order to supply the necessary background for the later cases it will be necessary to review the growth of the doctrine of uniformity, passing briefly over all but the developments of the last decade. The principle derives its existence from Section 2 of

1244 U. S. 205, 37 Sup. Ct. 524 (1917).

2 Wright, Uniformity in the Maritime Law of the United States (1925) 73 U. of PA. L. Rev. 123, 223; Fell, Recent Problems in Admiralty Jurisdiction (1922) 40 JonNs Hopkins UNIVERSiTy STudies 287; Dodd, The New Doctrine of the Supremaoy of Admiralty over the Common Law (1021) 21 CoL. L. Rev. 647; Palfrey, The Common Law Courts and the Law of the Sea (1923) 36 HARv. L. REv. 777; Cunningham, Is Every County Court in the United States a Court of Admiralty? (1919) 53 AM. L. Rev. 749; Cunningham, The Tables Trumed-Lord Colve Demolished (1921) 55 AM. L. REv. 685 . 
Article III of the federal Constitution, by which the judicial power is extended "to all cases of admiralty and maritime jurisdiction." Upon this scanty foundation a doctrine of far-redehing scope has been erected. In the beginning little or no attention seems to have been paid to the matter of uniformity or even to the nature of the substantive admiralty law. At an early date it was settled that the familiar system of "general maritime law" was to be applied in the admiralty courts. In the course of time it also became established that a general legislative power over the maritime law was impliedly vested in Congress by the Constitution.

However, the maritime jurisdiction thus granted to the federal government was never wholly exclusive of state authority, which was made effective in two ways. In the first place the courts of common law continued to exercise, as they had before, a jurisdiction in maritime cases concurrent with that of the admiralty courts. Whether or not this concurrent jurisdiction would have survived in the absence of federal legislation, it was at once sanctioned by Congress through the so-called saving clause in the original Judiciary Act of 1789. ${ }^{3}$ This clause conferred upon the federal district courts "exclusive original cognizance of all civil causes of admiralty and maritime jurisdiction. . . saving to suitors, in all cases, the right of a common-law remedy, where the common law is competent to give it."

Secondly, even in the courts of admiralty some cases were decided in accordance with state law and not under the general maritime law. Familiar illustrations are state statutes regulating pilotage, death acts and acts giving a maritime lien unon a vessel for repairs or supplies furnished in her home port.s These state laws were resorted to where the maritime law seemed inadequate, without inquiry as to the general status of such diverse elements in the admiralty. But the inquiry could not long be delayed and it resulted in the formulation of the first of three major stages of development through which the doctrine of uniformity has passed, namely, the uniformity of the system of law applicable in the admiralty courts in the absence of congressional legislation. Were divergent local laws to be the exception or the rule? To this question the natural answer was made that a uniform system of federal maritime law must be dominant; resort to state law on certain subjects, recognized to be usually local in character, was accepted more as a matter of precedent than of principle. The leading statement of these conclusions was made

31 STAT. 73, 76, 77 (17S9).

see examples enumerated in Southern Pacific Co. v. Jcnsen, supra note 
by the Supreme Court in 1875 in The Lottawanna, where Justice Bradley said:"

"That we have a maritime law of our own, operative throughout the United States, cannot be doubted. The general system of maritime law which was familiar to the lawyers and statesmen of the country when the Constitution was adopted, was most certainly intended and referred to when it was declared in that instrument that the judicial power of the United States shall extend 'to all cases of admiralty and maritime jurisdiction.' But by what criterion are we to ascertain the precise limits of the law thus adopted? The Constitution does not define it. . .

"One thing, however, is unquestionable; the Constitution must have referred to a system of law coextensive with, and operating uniformly in, the whole country. It certainly could not have been the intention to place the rules and limits of maritime law under the disposal and regulation of the several states, as that would have defeated the uniformity and consistency at which the Constitution aimed on all subjects of a commercial character affecting the intercourse of the States with each other or with foreign states."

The next major development in the uniformity of the substantive maritime law was not reached until 1917, when South. ern Pacific Co. v. Jensen was decided. A stevedore had been killed in New York harbor in the course of his maritime employment on board a vessel owned by a Kentucky corporation. An award was made to his widow under the New York workmen's compensation act and upheld by the state courts. The case thus differed from The Lottawanna in the important particular that it arose in the state tribunals instead of in admiralty. The Supreme Court of the United States, by a five-to-four vote, nevertheless reversed the judgment of the New York Court of Appeals on the ground that, as so applied, the compensation statute was in conflict with the federal Constitution. In so doing it laid down for the first time the broad constitutional doctrine that not only must uniformity be dominant in admiralty, but also the same body of maritime law must be applied by state tribunals in such maritime controversies as may come before them in the

1 , at 216, 246-247, 37 Sup. Ct. at 529, 541-542; also in The City of Norwalk, 55 Fed. $98,106-107$ (S. D. N. Y. 1893).

521 Wall. 558, 574 (U. S. 1874).

${ }^{6}$ An alternative ground given for the decision was that the remedy which the compensation statute attempts to give is of a character wholly unknown to the common law, incapable of enforcement by the ordinary processes of any court and hence not a "common-law remedy" within the scope of the saving clause which defines the concurrent jurisdiction of the stato tribunals. This, however, seems inconsistent with the position taken by the Court in the later case of Red Cross Line v. Atlantic Fruit Co., 264 U. S. 109, 44 Sup. Ct. 274 (1924). It is there said that the right of a commonlaw remedy saved to suitors includes "all means other than proceedings in admiralty which may be employed to enforce the right or to redress tho in- 
exercise of their concurrent jurisdiction. ${ }^{\circ}$ Even so it did not necessarily follow that the state act could not govern. For, as previously stated, local law is given effect in certain cases even in admiralty, and would be equally applicable in a common law court. This was of course recognized by the Supreme Court, which attempted to specify more closely than it had theretofore done the limits beyond which state legislation may not go. It said: ${ }^{7}$

"And plainly, we think, no such legislation is valid if it contravenes the essential purpose expressed by an act of Congress or works material prejudice to the characteristic features of the general maritime law or interferes with the proper harmony and uniformity of that law in its international and interstate relations. This limitation, at the least, is essential to the effective operation of the fundamental purposes for which such law was incorporated into our national laws by the Constitution itself. . . "

Applying this test to the controversy in question, it was held that the matters involved were of general rather than local concern, and that the necessary consequence of the application of the compensation statute would be destruction of the very uniformity in respect to maritime matters which the Constitution was designed to establish. The rights of the parties were thus dependent solely upon the maritime law.

The result of the Jensen decision is that, so far as substantive rights are concerned, it makes no difference whether a suitor brings his action in admiralty or in a common-low tribunal under the saving clause. Any departure by a state court from the maritime rules approved by the United States Supreme Court will be reversible upon review by the latter. It is this phase of the whole uniformity doctrine that has been the principal subject of controversy. Hostile criticism, which has been extensive, has been based largely upon the ground that there was no suffcient authority or precedent to justify the imposition of maritime law upon common-law courts. The Constitution of course has nothing expressly to say upon the point. Nor is there any extrinsic evidence available as to what, if anything, the framers thought about it. In the early cases the courts do not seem conscious of any problem. But whatever the original intention may have been, it became the regular practice of the state courts, though exceptions can be found, to apply in maritime cases the same local law which they normally administered. The result was that where maritime and common law diverged, the saving

jury involved;" that while a state may not provide a remedy in rem for any cause of action within admiralty jurisdiction, it is othertwise "free to adopt such remedies, and to attach to them such incidents, as it secs rit."

I Supra note 1, at 216, 37 Sup. Ct. at 529. 
clause gave a suitor a choice of rights as well as of forum. This practice had been so long continued that to the contemporary generation of admiralty lawyers it seemed a part of the traditional system. Hence, to those steeped in the tradition, the Jensen decision brought a decided shock. ${ }^{8}$

One of the striking features of the Jensen case is the complete failure of the majority opinion to recognize that there had been any such existing precedent, or that the uniformity involved differed from the uniformity under discussion in The Lottavanna - the authority principally relied on. Had the litigation arisen in admiralty, there would have been no occasion for the opinion to say more than it did. But in the light of existing practice and tradition and the prior decisions of the Court itself, the difference between a cause brought in admiralty and one arising in a state tribunal was of fundamental importance. Whether the majority did not fully appreciate this or simply chose to ignore it, we can only surmise.

Precedent aside, the objections made to the Jensen doctrine seem minor. It is said that common-law judges will be compelled to administer an unfamiliar system of law. Also, close questions of jurisdiction can no longer be avoided by bringing suit under the saving clause in a common-law court, where in the past the local law would have governed in any event. Now, such a court must always determine the jurisdictional question in order to know which system of law to apply. While these objections may have some force, they are offset by the logical and practical advantage of having the rights of the parties to a particular controversy determinable by a single standard of substantive law. As an original proposition it is difficult to see why one of two litigants should have the privilege, denied to his opponent, not only of choosing the forum, but of selecting one of two varying: sets of rules for the determination of the controversy. Once the choice is made, the defending party has no right of removal. Hence it is likely that, as the novelty wears off, the broad doctrine of Southern Pacific Co. v. Jensen will in its practical operation receive general approval. This at least seems to be the present trend of opinion within the admiralty bar.

Whatever the ultimate merits of the Jensen doctrine, its hostile reception was enhanced by its immediate effect in depriving longshoremen and similar workers of the benefits of workmen's compensation. Within a few months Congress had taken action to obviate this result through the passage of the Act of October

\footnotetext{
${ }^{8}$ See, for example, the articles by Cunningham, supra note 2 , and Hough, Admiralty Jurisdiction - of Late "Years (1924) 37 HARv. L. REv. 529, 587 et seq.; see also Justice Pitney, dissenting, in the Jensen case, supre note 1 , at 239, 37 Sup. Ct. at 538.
} 
6, 1917.9 The means adopted was an amendment of the saving clause, which had been in continuous effect since first enseted in 1789. To the old provision "saving to suitors, in all cases, the right of a common-law remedy, where the common law is competent to give it," was added "and to claimants the rights and remedies under the workmen's compensation law of any state."

In Knickerbocker Ice Co. v. Steucit, ${ }^{10}$ the question was presented to the Supreme Court whether this Act of 1917 was constitutional. In that case an award had been made under the New York compensation statute to the widow and children of a bargeman, who while doing work of a maritime nature had been drowned in the Hudson River. The award was approved by the Court of Appeals, but again its judgment was reversed by the Supreme Court by a five-to-four vote. The Act of 1917 did not do away with the effect of the Jciscn case, since the enactment was beyond the powers of Congress. In this decision the Supreme Court carried the uniformity requirement into its last and most extreme stage of development. While the opinion rests in part on the general principle of the non-delegability of legislative power, the major emphasis is placed upon the doctrine which the Court derives from the grant of judicial power to the federal government made by Section 2 of Article III of the Constitution. Speaking of Congress, the Court says: ${ }^{11}$

"Its power to legislate concerning rights and liabilities within the maritime jurisdiction and remedies for their enforcement, arises from the Constitution, as above indicated. The definite object of the grant was to commit direct control to the Federal Government; to relieve maritime commerce from unnecessary burdens and disadvantages incident to discordant legislation; and to establish, so far as practicable, harmonious and uniform rules applicable throughout every part of the Union.

"Considering the fundamental purpose in view and the definite end for which such rules were accepted, we must conclude that in their characteristic features and essential international and interstate relations, the latter may not be repealed, amended or changed except by legislation which embodies both the will and deliberate judgment of Congress. The subject was intrusted to it to be dealt with according to its discretion-not for delegation to others. To say that because Congress could have enacted a compensation act applicable to maritime injuries, it could authorize the States to do so as they might desire, is false reasoning. Moreover; such an authorization would inevitably destroy the harmony and uniformity which the Constitution not only contemplated but actually established-it would defeat the very purpose of the grant."

940 STAT. 395 (1917), $2 S$ U. S. C. $\$ \$ 41$ (3), 371 (1926).

10253 U. S. 149,40 Sup. Ct. 438 (1920).

11 Ibid. 164, 40 Sup. Ct. at 441. 
This argument involves two aspects. First, the maritime law, in its characteristic features and essential international and interstate relations, may not be changed except by the direct legislation of Congress, embodying its will and deliberate judgment. The constitutional grant in itself precludes any authorization to the states to legislate or any adoption of prospective state legislation. Secondly, the Constitution makes geographical uniformity a requisite of any federal legislation within the same field. Possibly this second point was unnecessary to the decision, but it has been generally assumed (by the dissenting judges, among others) that such is the effect of the Stewart case. The difference between the two limitations is material. For Congress might, consistently with the first, provide for the varying needs of different localities through the establishment of districts and the formulation of non-uniform rules applicable thereto; or, as the dissenting opinion suggests, even the Act of 1917 could have been upheld by construing it to refer solely to state laws in force at the time of its passage, the same being incorporated by reference. But if all federal legislation must have a uniform operation, any such course is foreclosed.

In the controversy over the Jensen case, the significance of this Stewart decision and the extent to which it carries the uniformity requirement beyond the scope of the earlier cases have not received a due share of attention. The Lottawanna merely declared that uniformity must be dominant in the non-statutory maritime law, no question of congressional power being involved. In Southern Pacific Co. v. Jensen the question was one of uniformity as between courts, the conclusion being that the same substantive law must be applied by all courts before which a maritime controversy may be brought and that this law constitutes a federal system over which Congress was declared to have a paramount legislative power. The uniformity doctrine as thus applied involves an extension of federal supremacy at the expense of the states. In Knickerbocker Ice Co. v. Stewart the uniformity doctrine operates as a limitation upon the powers of Congress and hence involves an extension of the powers of the courts at the expense of the legislative branch of the Government. Since uniformity is imposed by the Constitution, only the courts can say how far it goes. The consequence of the decision is that Congress is deprived of power to determine what matters within the admiralty jurisdiction need adaptation to varying local conditions and what call for treatment by uniform rules. That diversity is desirable in some cases and uniformity in others has always been, recognized. There has always been a border zone in which state law has been applied to matters principally of 10cal concern. Of course this area of non-uniformity may be re- 
duced by Congress, as when the state statutes giving a lien unon a vessel for supplies and repairs furnished in a home port were superseded by the uniform federal Lien Act.2 This is an incident of its paramount legislative power. Prior to the recent decisions it would have been supposed that Congress had equal power to enlarge the area of diversity, that in either event no more was involved than the substantive content of the maritime law. Now, while Congress may still extend the field of uniformity it may not reduce it beyond the limits fixed by the courts.

The vital distinction between the uniformity of the Jcisscin case and the uniformity of the Stercart case is thus plain. And the difference leads to distinctly greater difficulty in considering the justifiability of the respective doctrines. The principal trouble with the Jensen case was that of finding sufficient warrant in the Constitution for imposing the maritime law upon the state courts. In the Stewcit case not only is the corresponding difficulty enhanced by the greater lengths to which the uniformity principle is carried, but also whether the result is in accordance with practical wisdom or sound statesmanship is open to grave doubt.

As to the constitutional authority, it must always be remembered that the entire uniformity principle is derived from the simple grant of judicial power over "all cases of admiralty and maritime jurisdiction." The Constitution says nothing about uniformity; in fact there are no express provisions of any lind with respect to the substantive maritime law or the legislative power thereover. The nearest thing we have to a contemporaneous interpretation-the saving clause of the original Judiciary Act-makes clear that complete uniformity is not required. For whatever may have been intended with regard to the substantive law, the saving clause makes uniformity of remedy impossible. Uniformity is secured, to be sure, as to the typical admiralty remedy-the action in rem-since the latter is not within the scope of the saving clause and hence is restricted to the admiralty courts. ${ }^{13}$ But other remedies, which are within its terms, are as diverse as the procedural laws of the various states. $^{\text {Is }}$ So far as the Jensen case is concerned, the state courts in the exercise of their concurrent jurisdiction had to apply either state law or maritime law, and no decisive argument either way can be derived from the letter of the Constitution. With the result reached by the Supreme Court, the writer is not disposed to quarrel. Although in conflict with existing precedent, it

1236 STAT. 604 (1910), 46 U. S. C. \$\$ 971-975 (1926).

13 The Mioses Taylor, 4 Wall. 411 (U. S. 1867); The Hine v. Trevor, 4 Wall. 555 (U. S. 1867).

${ }_{14}$ Red Cross Line v. Atlantic Fruit Co., supra note 6; Innapp, Stout $\mathcal{E}$ Co. v. MicCaffrey, 177 U. S. 638, 20 Sup. Ct. 824 (1900). 
may be, as Professor. Wright thinks, ${ }^{15}$ in harmony with the needs and larger tradition of admiralty law. The writer is unable, however, to view with equal complacency the doctrine of Knickerbocker Ice Co. v. Stewart.

Certainly it is customary to assume that limitations upon the legislative power are not to be lightly imposed, and where the restriction must rest solely upon implication it would seem that no more should be implied from the written Constitution than is necessary to the fulfilment of its expressed purposes. The crux of the matter thus appears to be whether or not it is essential to the protection of the constitutional grant of judicial power over all cases of admiralty and maritime jurisdiction to deny to Congress the power to control the matter of uniformity in the substantive law. No doubt we may properly conclude that the purpose of the grant was to remove the maritime law from the direct control of the states with their local and conflicting interests and to vest control in Congress. The Jensen case does not necessarily mean more than this. ${ }^{16}$ But it is hard to say that the national and international interests concerned cannot safely be intrusted to Congress. The fairer conclusion would seem to be that paramount power to fix and determine the maritime law includes the power to determine the extent to which uniformity of rule is needed. Indeed there is much force in the remark of Justice Holmes in his dissenting opinion in the Stevvart case, that: ${ }^{17}$

"To read into it [the clause concerning the judicial power] a requirement of uniformity more mechanical than is educed from the express requirement of equality in the Fourteenth Amendment seems to me extravagant."

The practical question is not whether there should be uniformity, but whether the power to determine how far it shall extend ought to rest in the legislative or in the judicial branch of the Government. Not only is there scant basis for the belief that

15 Wright, op. cit. supra note 2.

16 In the Jensen case no act of Congress was under attack. The only federal enactment involved was the saving clause, which saves a commonlaw remedy but is silent as to the substantive law to be applied in commonlaw tribunals. The decision might have rested merely on the absence of congressional authorization to such tribunals to apply local instead of maritime law. At most the reasoning of the opinion should require that a federal statute be held unconstitutional which specifically authorized tho application of local law in local tribunals, where that law differed from the rules enforceable in admiralty. But there is an essential differenco between such a restriction and the taling from Congress of the power to control the matter of uniformity in the single system of substantivo law which is to govern in all courts in maritime cases.

17 Supra note 10, at 168, 40 Sup. Ct. at 443. 
Congress is not a fit judge of such matters, but in its very nature the subject is legislative rather than judicial. In many situstions uniformity is highly desirable, if not essential, to the protection of national interests; in others adaptation to local needs and even subjection to local control is likewise desirable. This is so even as to workmen's compensation, as the later cases make clear. Where the line should be drawn must depend upon actual conditions and the practical needs of the situation. It is not a case for pure logic or theoretical speculation, but for the determination of facts. It is a job for the legislative body, with its capacity for investigation and its closer contact with the world's activities. Furthermore, the field is one in which conditions may change. A matter which at one period may saiely be left to local control may need uniform regulation at another, and viceversa. The public interest is not served by the application of constitutional rigidity, reinforced by the doctrine of stare decisis, to matters which ought to be mobile and capable of adjustment to changing conditions.

This view is not without pragmatical support. For the actual course of events indicates that Congress is likely to be no less realistic than the Supreme Court in dealing with the problem of uniformity. No doubt Congress in its haste went too far in enacting the Act of 1917 in a form broad enough to include seamen within its scope. On the other hand, with regard to longshoremen and other harbor workers the Supreme Court has quite lost sight of the realities of the situation. Its position on this point was re-emphasized by its later decision in Statc of Washington v. W. C. Dawson \& Co. ${ }^{13}$ Following the Stcuart decision Congress had made a further attempt to evade the rigid restriction imposed upon it with respect to uniformity. On June 10, 1922, an act was adopted, ${ }^{19}$ which reenacted the provision of the Act of 1917, saving to claimants their rights and remedies under the workmen's compensation law of any state, but excepted from its operation "the master or members of the crew of a vessel." In the Douson case the Court held that this amendment was insufficient to remove the objections set forth in Knickerbocker Ice Co. v. Stezcart and declared the Act of 1922 likewise unconstitutional. It was even held that a state compensation statute could not be applied to a stevedore employed on board ship, not by the shipowner as in the Jcascin case, but by an independent contracting stevedoring company.

This decision makes clear, if further clarity were needed after the Stewart case, that Congress has no power to confine the uniformity requirement within narrower limits than those approved by the Supreme Court. The Dawson case also reiterates

18264 U. S. 219, 44 Sup. Ct. 302 (1924).

1942 SтAт. 634 (1922), 28 U. S. C. $\$ \$ 11$ (3), 371 (1926). 
the conclusion of the Court that uniformity is required with respect to the rights of a stevedore injured on navigable waters. In other words, his rights are not of merely local concern, but involve either the characteristic features or the essential international or interstate relations of the maritime law-presumably the former, since there is no indication that the result depends upon whether or not the ship in question is engaged in interstate or foreign commerce.

One may well wonder what practical end is gained by this requirement of geographical uniformity in the rights of injured stevedores, especially when in the service of a local independent contractor. Where both employer and employee are local residents, whose interests are local, and the service is performed wholly in a single port, little good is accomplished by identity of the workman's rights to compensation in New York and San Francisco. It means nothing either to employer or to employee, and the shipowner has no direct concern with the matter. Justification may be found only in the realm of pure theory, uncontaminated by reality. Where a harbor worker is employed directly by the ship on which he works, the argument for uniformity has somewhat more substance. From the point of view of the shipowner it may be helpful to have his responsibilities determined so far as possible by a single standard, wherever the vessel may go. But the point of view of the employee should not be disregarded. He is not an itinerant and so far as his interests are concerned, there is no reason why he should be treated differently from his fellow-workers on land. And uniformity on the water makes adaptation to local conditions and standards of living impossible. Moreover, if he works both on land and on water, as does a stevedore, the uniformity of his own rights is destroyed. If he happens to suffer injury on shore or on the wharf, his rights are determined by state law; if the accident occurs on board ship, the maritime lnw governs. Owing to the introduction of workmen's compensation, this lack of uniformity has resulted in real hardship. ${ }^{20}$ Furthermore, the benefit to the shipowner in this situation is no more than nominal, since if any of the labor is performed on land it is necessary for him to insure under the state compensation act in any event. As a matter of both public and private interest, the slight gain to him from geographical uniformity is outweighed by the importance of uniformity in the rights of the individual employee and of uniformity as between different classes of local workers. In short, a geographical uniformity

${ }^{20}$ See references cited by Justice Brandeis in his dissenting opinion in State of Washington v. Dawson '\& Co., supra note 18, at 237, n. 20, 44 Sup. Ct. at 309, n. 22. 
of little more than theoretical value has been achieved at the expense of practical justice.

This marks the farthest extent to which the uniformity requirement has been carried. Rightly or wrongly, the doctrines developed by these cases are now a part of our organic law. Despite the close vote by which they were established, they are, in their main features at least, here to stay, since there is little prospect of more than minor modifications. The forceful dissenting opinion of Justice Brandeis in State of Washingtan $i$. Dawson \& Co. is the swan song of a lost cause. This establishment of uniformity, however, is by no means the end of the story so far as workmen's compensation is concerned. It is plain that in most cases the state compensation acts can have no aplication to maritime injuries. But questions remain which have been a source of difficulty and confusion to both bench and bar. What are the limits of admiralty jurisdiction with respect to workmen's compensation? And within that jurisdiction what room is there left for the application of the compensation statutes of the states? Finally, the scope and effect of federal compensation legislation remain to be considered.

\section{THE PLACE LEET TO STATE COMPENSATION ACTS}

Injuries on land. In the cases so far discussed the matters involved fell well within the limits of maritime jurisdiction. Hence there was no occasion to consider what those limits are so far as workmen's compensation is concerned. Difficulty may arise in this regard owing to the fact that there is no single test of jurisdiction in admiralty. In matters of tort the jurisdiction depends upon locality-the injury must occur upon navigable waters. ${ }^{21}$ In contract cases the subject-matter of the contract is decisive. If the subject-matter is maritime, admiralty has jurisdiction; otherwise not, and in either event the place of making or performance is not controlling."n In the Jcnscn, Stewart and Dowson cases both of these tests were met. The contracts of employment were maritime in nature and the injuries occurred on board ship or elsewhere upon navigable waters. But an employee may be injured on land while engaged in the performance of a maritime contract, or upon the water while performing a non-maritime contract. According to one test of jurisdiction the matter is maritime; according to the other it is not. Which shall govern when a state worlmen's compensation act is sought to be applied?

${ }^{21}$ The Plymouth, 3 Wall. 20 (U. S. 1S66); Atlantic Transport Co. Imbrovek, 234 U. S. 52, 34 Sup. Ct. 733 (1914).

${ }^{22} \mathrm{NeV}$ England MIutual Insurance Co. v. Dunham, 11 Wall. 1 (U. S. 1871) ; North Pacific S. S. Co. v. Hall Bros. Co., 249 U. S. 119, 39 Sup. Ct. 221 (1919). 
The first of these two situations was presented to the Supreme Court in State Industrial Commission v. Nordenholt Corp.". This case, like the Jensen and Dawson cases, involved injuries to a stevedore suffered in the course of his maritime employment. The difference lay in the fact that the accident occurred on the dock ( $i . e$. , on land), instead of on board ship. An order awarding compensation was made by the Industrial Commission of New York, but was reversed by the Court of Appeals. The conclusion reached by the latter court that the state statute could ' not be applied, was based upon its views as to the nature of workmen's compensation. ${ }^{24}$ It followed the widely-held theory that the obligation imposed by compensation acts, even of the compulsory type, is contractual in nature, that the statute giving the commission power to make an award is read into and becomes a part of the agreement. Since a stevedore's contract of employment is maritime, it was concluded that the application of the state statute would amount to the regulation of a maxitime contract and hence would constitute an infringement upon the jurisidiction of admiralty. This judgment, however, was reversed by the United States Supreme Court. A superficial view of its decision may lead to the supposition that jurisdiction for purposes of workmen's compensation is determined by the tort test of locality rather than by the contract test of subjectmatter. But a closer examination of the opinion will revenl that this is not necessarily the case. The Supreme Court approached the issue from a fundamentally different point of view from that of the state Court of Appeals, and looked not at the nature of workmen's compensation, but at the existing state of the maritime law. It said: ${ }^{25}$

"Insana was injured upon the dock, an extension of the land, (Cleveland Terminal \& Valley R. R. Co. v. Cleveland S. S. Co., 208 U.S. $316 \ldots$...), and certainly prior to the Workmen's Compensation Act the employer's liability for damages would have depended upon the common law and the state statutes. Consequently, when the Compensation Act superseded other state laws touching the liability in question, it did not come into conflict with any superior maritime law. And this is true whether awards under the act are made as upon implied agreements or otherwise. The stevedore's contract of employment did not

${ }^{23} 259$ U. S. 263, 42 Sup. Ct. 473 (1922). The decision was followed in T. Smith \& Son v. Taylor, 48 Sup. Ct. 228 (U. S. 1028).

24 See Doey v. Howland Co., Inc., 224 N. Y. 30, 120 N. E. 53 (1018), cert. denied, 248 U. S. 574, 39 Sup. Ct. 11 (1918); Anderson v. Johnson Lighterage Co., 224 N. Y. 539, 120 N. E. 55 (1918), cert. denied, 248 U. S. 574, 39 Sup. Ct. 11 (1918); Keator v. Rock Plaster Manufacturing Co., 224 N. Y. 540, 120 N. E. 56 (1918), cert. denied, 248 U. S. 574, 39 Sup. Ct. 12 (1918).

${ }^{25}$ Supra note 23 , at 275,42 Sup. Ct. at 475 . 
contemplate any dominant federal rule concerning the master's liability for personal injuries received on land. In Jensen's case, rights and liabilities were definitely fixed by maritime rules, whose uniformity was essential. With these the local law came into conflict. Here no such antagonism exists. There is no pertinent federal statute; and application of the local law will not work material prejudice to any characteristic ferture of the general maritime law."

This paragraph makes clear that in the Nordentholt case no question of jurisdiction at all is actually decided. It has been recognized in all these cases that uniformity is not required throughout the entire field of admiralty jurisdiction, but only as to the characteristic features of the general maritime law and its essential international and interstate relations. And where uniformity is not necessary, admiralty has often been accustomed to resort to state law to supplement its own rules. Here we have a situation, involving personal injury to a harbor worker suffered on land, to which no existing rules of the maritime law are applicable. To deal with the matter on a tort basis, as is done when the injury is on navigable waters, would be beyond the limits of admiralty jurisdiction. And the maritime law gives an injured harbor worker (unlike a sesman) no rights of a contractual nature. Under these circumstances it is obvious that no characteristic feature of the general maritime law can be prejudiced by the application of a state compensation statute. Unless local law of some sort is resorted to, injured workmen will be totally without relief.

The Nordenholt decision may thus be supported, regardless of the real nature of workmen's compensation or of the ultimate limits of admiralty jurisdiction. What those limits are for purposes of compensation legislation has never been decided by the Supreme Court. In order to raise the question in this situation, it would be necessary to inquire whether or not the maritime law could be so extended as to supersede the law of the state. Precisely this problem would be presented, if Congress should pass a workmen's compensation act applicable to all injuries arising out of and in the course of maritime employment, regardless of their location. It would seem that the validity of such an act could not be determined without considering the nature of workmen's compensation and fitting it into the categories of admiralty jurisdiction. The answer should not be difficult. If the federal legislation sounded in tort, it would of course be unconstitutional as applied to an injury on land, since it would exceed the bounds of a jurisdiction limited by locality. It is generally agreed, however, that workmen's compensation, which imposes liability irrespective of fault, does not rest on any theory of tort. Such legislation is commonly explained 
either upon a contract theory-the view taken by the New York courts-or upon a theory of status, the idea being that the obligation to pay compensation is a statutory one imposed by law upon the status of employer and employee. Though the relation has its inception in a contract, once created its incidents depend not merely upon the agreement of the parties, but upon the provisions of the law. ${ }^{26}$

According to the first of these two theories, the supposed federal act would clearly be valid in its application to land injuries. For it would be no more than the regulation of a maritime contract-an exercise of a jurisdiction as to which locality is not controlling. If the second theory were followed, the question would be whether legislation regulating the incidents of a status arising out of maritime employment should be governed by the tort test or the contract test of admiralty jurisdiction. Here it seems almost equally plain that the regulation of the rights and obligations of maritime employment, whether or not strictly a matter of contract, is more closely identified with the field of contract than with the field of tort. Certainly in order to be fully effective, such regulation should govern the entire employment, wherever the services may be performed. It follows that the state compensation statute would be displaced by the federal act, and the result of Industrial Commission v. Nordenholt Corp. reversed. Hence it seems that viewed purely as a matter of jurisdiction, the conclusion reached by the New York court in that case was sound, and that its reversal by the federal supreme Court must rest solely upon the ground that, regardless of jurisdiction, the state law did not work material prejudice to any characteristic feature of the general maritime law.

In the event of federal legislation such as that supposed, another question of some theoretical interest would arise with respect to the conflict between the federal statute and the tort law of a state. An injury to a maritime employee on land would fall with the contract jurisdiction of admiralty, but equally within the jurisdiction of the state so far as tort law is concerned. Thus both federal and state laws could provide recompense for the same injury without, considered alone, exceeding their proper sphere. Of course the employee could not have a double recovery. Conceivably he might have an option as to which remedy to pursue, but it is probable that the federal law would have exclusive application. Since a remedy in workmen's compensation is normally made exclusive of all other remedies, the federal act could not be given full effect without displacing

${ }^{26}$ See North Alaska Salmon Co. v. Pillsbury, 174 Cal. 1, 162 Pac. 93 (1916); Angell, Recovery under Workmen's Compensation Acts for Injury Abroad (1918) 31 HARV. L. REv. 619. 
the state law of torts, and if either must yield, it should be the latter.

A clear understanding of the Nordcnholt decision is material in considering another and perhaps the most important question remaining undecided with regard to the state compensation acts -namely, whether they may be applied to a seaman, who in the course of his employment is injured on the shore or dock. Superficially this resembles the Nordenzolt case. The difference lies in the differing rights which our non-statutory maritime law gives to an injured seaman, as compared with an injured stevedore or other harbor worker. The rights of the latter lie simply in a tort action for damages based on negligence, substantially similar to (and in fact derived from) those given an injured workman by the common law. ${ }^{27}$ The rights of an injured seaman, derived from the general maritime law, are quite different. ${ }^{2 s}$ If he falls sick or is wounded in the service of his ship, he is entitled to his wages to the end of the voyage and to his maintenance and cure for the same period and probably for a reasonable time thereafter. This right exists regardless of the negligence of his employer, his fellow-seamen or himself. Beyond that he is entitled to an indemnity, i. c., to compensatory damages, only for injuries received in consequence of the unseaworthiness of the ship, or a failure to supply and lieep in order the proper appliances appurtenant to the ship.

Mich as these rights of the seaman vary from those of an injured harbor worker, the difference might not be material for our purposes if the former, like the latter, rested upon a tort basis. According to the notions of the maritime law, however, such is not the case. In admiralty the right to wages, maintenance and cure has always been regarded as contractual in nature, being derived by implication from the seaman's contract of employment. ${ }^{29}$ In fact it bears a striling resemblance to workmen's compensation itself. In both cases the employer is under a legal obligation, arising either out of the contract, or out of the relation created by contract, to aid an employee who suffers injury in the course of his employment. And in both cases the obligation exists regardless of fault. So far as the nature of the obligation is concerned, it would seem to be identical in the two cases, and it should be governed by the contract test rather thin

${ }^{2 \pi}$ Atlantic Transport Co. v. Imbrovek, stpra note 21; Southern Pacific Co. v. Jensen, supra note 1 , at 220,37 Sup. Ct. at 581.

28 The Osceola, 189 U. S. 158, 23 Sup. Ct. 488 (1908); Chelentis v. Luckenbach S. S. Co., 247 U. S. 372, 38 Sup. Ct. 501 (1918); Smith, Liability in the Admiralty for Injuries to Seamen (1906) 19 Harv. L. Rev. 418.

29 The Osceola, supra note 28; Cresci v. Standard Fisherics, 7 F. (2d) 378 (N. D. Cal. 1925) ; see The Atlantic, 2 Fed. Cas. 121, 180 (S. D. N. Y. 1849). 
the tort test of jurisdiction. Hence a seaman injured on land in the service of his ship should be entitled to wages, maintenance and cure. This result has recently been reached by the Circuit Court of Appeals for the Second Circuit. ${ }^{30}$

The nature of the seaman's right to indemnity for injuries due to unseaworthiness of the ship or to defective appliances cannot be stated with the same certainty. This right did not exist under the early maritime codes. It was created in England by statute, and in the United States by judicial decision. ${ }^{31}$ Under the English statute it seems clear that the right to indemnity, like the right to wages, maintenance and cure, was contractual in nature. The statute ${ }^{32}$ provided that "In every contract of service, express or implied, between the owner of a ship and the master or any seaman thereof . . . there shall be implied, notwithstanding any agreement to the contrary, an obligation on the owner of the ship" that all reasonable means shall be used to insure the seaworthiness of the ship. In this country also the shipowner's obligation to pay compensatory damages has been regarded by some commentators as grounded in contract. The recent tendency of the federal courts, however, has been to treat an action for indemnity on a tort basis, and jurisdiction in admiralty has been denied where the seaman was injured on land. ${ }^{3 *}$

${ }^{30}$ The Montezuma, 19 F. (2d) 355 (C. C. A. 2d, 1927); see also BENEDicr, ADMrRaLTY (5th ed. 1925) §§ 27, 29.

31 The Osceola, supra note 28, at 175, 23 Sup. Ct. at 487; 2 PArsons, SHIPPING AND ADMIRALTY (1869) 78.

32 Merchant Shipping Act of 1876, 39 and 40 Vict. c. 80, § 5; see Hedloy v. Pinckney \& Sons S. S. Co., [1894] A. C. 222.

${ }^{33}$ Smith, op. cit. supra note 28, at 432; Hughes, ADMIRAuTY (2d ed. 1920) $\S 101$.

34 The Mary Garrett, 63 Fed. 1009 (N. D. Cal. 1894); The Montezuma, supra note 30.

In the Montezuma, a libel in admiralty was filed by a seaman for damages for personal injuries received on a dock. The district court dismisscd the libel for lack of jurisdiction on the ground that the jurisdiction involcd was ex delicto and must be determined by the locality of the injury. 15 F. (2d) 580 (W. D. N. Y. 1926). The Circuit Court of Appeals approved this conclusion so far as compensatory damages were concerned, but reversed the judgment on the ground that the libellant should have bcen allowed a recovery for maintenance and cure.

In the following cases, it was held that the rights under the Fedoral Employers' 'Liability Act extended to seamen at their option by the Jones Act [41 STAT. 1007 (1920), 46 U. S. C. $\S 688$ (1926)] do not apply to injuries received on land: Hughes v. Alaska S. S. Co., 287 Fed. 427 (W. D. Wash. 1923) ; Soper v. Hammond Lumber Co., 4 F. (2d) 872 (N. D. Cal. 1925); Todahl v. Sudden \& Christenson, 5 F. (2d) 462 (C. C. A. 9th, 1925). For the contrary view, see BENEDrCT, op. cit. supre noto 30, \$ 25; Magruder \& Grout, Wrongfill Death within the Admiralty Jurisdiction (1926) 35 YALE L. J. 395, 429. The cases cited seem correctly decided, 
If it should ultimately be determined that the right to indemnity, together with that to wages, maintenance and cure, is a matter of contract, the conclusion is inevitable that a state workmen's compensation act could no more be applied to a sesman injured on land than to one injured on the water. In either event the substantive rights given by the maritime law would be the same. And regardless of the difference between such rights and those given by the state statute, it cannot be said that the maritime law does not cover the field. Hence a conflict between the two systems exists, which was not present in the case of a stevedore injured on land. Obviously, characteristic features of the general maritime law are involved in the law of seamen, and the state law must yield. The situation would be substantially the same as if a federal compensation act were in force, applicable to seamen and covering all injuries arising out of and in the course of their employment.

Suppose, however, that the seaman's right to indemnity is to be placed on a tort basis. If injured on land, his rights under the maritime law will then be confined to wages, maintenance and cure. Even this right, it would seem, would have to be denied him, had the Nordenholt decision rested on jurisdictional grounds. If jurisdiction for purposes of workmen's compensation were determined by locality, the right to maintenance and cure should be similarly limited, since the two seem indistinguishable from the jurisdictional point of view. But if the Nord $\mathrm{Cl}$ holt case has been correctly analyzed, it does not involve jurisdiction but rests upon the ground that the state statute did not come into conflict with any characteristic feature of the general maritime law. Then the present question will depend upon whether there is a similar absence of conflict in the seaman's case. Such conflict may be avoided only upon the assumption that the workmen's compensation remedy may covei the field occupied in the maritime law by the right to indemnity, without overlapping the right to wages, maintenance and cure.

So far as the two maritime rights are concerned, they may readily be regarded as separable. The one reimburses a seaman for the actual expense of maintenance and care made necessary by his injury; the other compensates him for such additional damage as he may have suffered. The two are supplementary. For example the receipt, even as the result of suit, of wages and the cost of maintenance and cure is no bar to a sub-

since the right given by the Employers' Liability Act is merely a modifieation of the common-law right to damages for personal injury and hence is clearly in tort. For the same reason these cases are not of weight in considering the application to land injuries of the right to indemnity given by the maritime law. 
sequent libel for indemnity. ${ }^{35}$ It follows that any state law, the function of which could be made equivalent to that of the maritime right of indemnity, could be applied to a seaman injured on land. There would be no objection to an ordinary common-law action in tort for damages for personal injury. A state employers' liability act should not differ, since, unlike workmen's compensation, it is founded in tort, merely removing certain common-law defenses. ${ }^{36}$ Distinctly greater difficulty is presented by the state workmen's compensation statutes. They purport to cover the entire field of rights and remedies accruing to an injured workman. Even the limited interest protected by the right to maintenance and cure must be included within their scope. ${ }^{37}$ It cannot be specially excluded in determining the amount of the award, as might be done in a tort action, since the scale of compensation is rigidly fixed by the statute itself. Moreover, the liability imposed upon the employer by a typical act is expressly made exclusive of all other liability. The state statute thus could not be given effect without superseding the seaman's maritime right to maintenance and cure. But state law will not be permitted so to supersede a rule of the maritime law where characteristic features of the latter are involved. And one of the most characteristic rules of the admiralty is involved in the right to wages, maintenance and cure.

Furthermore, when the practical effect upon uniformity is considered, it seems altogether probable that the Supreme Court will find the right to wages, maintenance and cure sufficient to prevent the application of state compensation acts to seamen injured on land. Nowhere is uniformity more essential than in the relations of a seaman to his ship, and it sometimes happens that in the course of his duties he is required to go on shore or on the dock. If on every such occasion it were necessary for the shipowner to insure under and otherwise comply with the

35 The Rolph, 299 Fed. 52 (C. C. A. 9th, 1924), cert. denied, 266 U. S. 614, 45 Sup. Ct. 96 (1924); see also The A. Heaton, 43 Fed. 592 (D. Miass. 1890) ; John A. Roebling's Sons Co. v. Erickson, 261 Fed. 986 (C. C. A. 2d, 1919), cert. denied, 252 U. S. 585, 40 Sup. Ct. 394 (1920).

${ }^{38}$ The receipt of wages, maintenance and cure does not bar an action under the Federal Employers' Liability Act, the benefits of which are oxtended to seamen by the Jones Act. Peterson v. Pacific S. S. Co., 145 Wash. 460, 261 Pac. 115 (1927), cert. granted, 276 U. S. 612, 48 Sup. Ct. 321 (1928) ; cf. supra note 34. But an unsuccessful suit in admiralty for indomnity will bar a subsequent action under the Jones Act. Baltimore S. S. Co. v. Phillips, 274 U. S. 316, 47 Sup. Ct. 600 (1927).

${ }^{3 \pi}$ The existence of such conflict has been expressly recognized in tho British Workmen's Compensation Act, which is applicable to seamon, in a provision to the effect that the weekly payment of compensation shall not be payable in respect of the period during which a shipowner may bo liable under the Merchant Shipping Act to pay the expenses of maintonanco of the injured seamen. 6 EDW. VII, c. 58, § 7 (1907). 
local compensation statute, the lack of uniformity would be distinctly more serious than in any case involving a stevedore who is locally employed, regardless of the place of his injury. Such diversity of rule would be permitted by the Supreme Court only with the greatest reluctance.

Injuries on navigable waters. The preceding discussion has been devoted to injuries occurring on land. The application of state workmen's compensation acts to injuries upon navigable waters will next be considered. The Jensen and Dau'son cases have established that the state statutes cannot be applied to a stevedore injured on the water. A fortiori a seaman so injured is beyond their reach. But some labor performed there has a more remote connection with shipping and navigation. The contract of employment may not even be maritime at all. If it is non-maritime, may the state compensation statute control? This question, the converse of that involved in Stotc Industival Commission v. Nordenholt Corp., was presented to the Supreme Court in Grant Smith-Porter Co. v. Rohde.33

Rohde was injured while at work as a carpenter upon a partially completed vessel lying in navigable waters within the state of Oregon. His contract of employment was non-maritime, since it is settled that such is the status of contracts for ship-construction, even as to work done after launching." There was in effect in Oregon a compensation act of the optional type, the parties being required to notify the proper state authority if it was desired not to come under the act. Neither Rohde nor his employer had given such notification and all steps required to bring the employment within the statute had been talien. Rohde, however, did not seek compensation, but filed a libel in admiralty against his employer to recover damages for personal injury. The case came to the Supreme Court on certificate from the Circuit Court of Appeals. The questions certified were: "1. Is there jurisdiction in admiralty because the alleged tort occurred on navigable waters? 2. Is libelant entitled because of his injury to proceed in admiralty against respondent for the damages suffered?" The answers given by the Supreme Court were as follows: ${ }^{\text {* }}$

"Construing the first question as meaning to inquire whether the general admiralty jurisdiction extends to a proceeding to recover damages resulting from a tort committed on a ressel in process of construction when lying on navigable waters within a. State, we answer, yes.

38257 U. S. 469 , 42 Sup. Ct. 157 (1922).

s9 Thames Towboat Co. $v$. The Francis McDonald, 251 U. S. 242,41 Sup. Ct. 65 (1920); Roach v. Chapman, 22 How. 120 (U. S. 1S59); People's

Ferry Co. v. Beers, 20 How. 393 (U. S. 1857).

so Supra note 38 , at 477,42 Sup. Ct. at 159 . 
"Assuming that the second question presents the inquiry whether in the circumstances stated the exclusive features of the Oregon Workmen's Compensation Act would apply and abrogate the right to recover damages in an admiralty court which otherwise would exist, we also answer, yes."

The certification of the first of these questions calls for some explanation. It must have been due to doubt as to whether locality is the exclusive test of tort jurisdiction in admiralty, as has generally been assumed, or whether it must also appear that the tort was otherwise of a maritime nature. The possibility of some such requirement had been noticed by the Supreme Court, but the question had been left undecided. ${ }^{41}$ If such an addition should be made to the locality test, it might well be argued (as it was argued by counsel in the Rohde case) that the test is not met when the tort occurs in the course of the performance of a non-maritime contract. Such a conclusion would have made further consideration of the Rohde case unnecessary, since if neither the contract nor the tort were maritime, there would be nothing to prevent the application of the state statute. The Court, however, held that the general admiralty jurisdiction did extend to such a proceeding. The basis for this result is left unexplained. Either it means that locality is to be the sole test in tort cases, or that ship-construction, though deemed non-maritime for purposes of contract, has a sufficiently close connection with shipping and navigation to satisfy such additional limitation as may be imposed.

Assuming then that the transaction did fall within the tort jurisdiction of admiralty, we may next inquire why it is that the state law may govern. The Court decided this point upon the same ground upon which it rested its decision in the Nordenholt case, holding that under the circumstances of the case the local law would not work material prejudice to any characteristic feature of the general maritime law, nor interfere with the proper harmony or uniformity of that law in its international or interstate relations. Again, as in the Nordenholt case, this argument made it unnecessary to consider the jurisdictional aspects of workmen's compensation.

Although at present of no more than theoretical interest, the matter of jurisdiction may, however, be worth a moment's digression. The conclusion reached earlier in this article was that power to pass compensation legislation should be determined by the contract test and not the tort of jurisdiction. If this is correct, Congress could not enàct a federal compensation law

$\$$ Atlantic Transport Co. v. Imbrovek, supra note 21. Outside of the decisions of the Supreme Court, there is authority to support the addition of such a limitation to the locality test. Campbell v. H. Hackfeld \& $\mathrm{Co}_{\text {. }}$ 125 Fed. 696 (C. C. A. 9th, 1903); BENEDICT, op. cit. supro note 30, 127. 
applicable to employment under a non-maritime contract even though performed upon navigable waters. But it does not necessarily follow that state legislation of the same sort could constitutionally be applied. The difficulty is due to the inconsistent tests of admiralty jurisdiction in contract and in tort. Here, although the contract jurisdiction is clearly vested in the state, the Supreme Court holds that the transaction falls within the tort jurisdiction of admiralty. And the trouble with a state compensation statute is that, though founded in contract, it is made exclusive of all other remedies. Hence it could not be given full effect without destroying the right to a tort action in admiralty. So far as jurisdiction is concerned, it seems plain that a state could not so exercise its contract jurisdiction as to prevent the exercise by admiralty of its jurisdiction in tort. The state statute might be upheld provided the provision making its remedy exclusive were so modified as to leave the worlsmen an option to pursue a tort action in admiralty. But the exclusiveness of the statute's operation can be sustained only upon the theory adopted by the Supreme Court, that the transaction is merely of local concern and outside the scope of the uniformity requirement. ${ }^{22}$

One result of this is that the exclusive operation of the state statute is dependent upon the will of Congress. For the paramount legislative power of that body extends not merely to the zone within which uniformity is necessary but to the full limits of admiralty jurisdiction, so that the application of any state law within that jurisdiction may be terminated by conflicting federal legislation. Thus there is nothing to prevent Congress from establishing rules of substantive law controlling a case like Rohde's, provided those rules are based upon the principles of tort. So far as the state law were incompatible therewith, the local rules would have to vield.

Fortunately it is not probable that Congress would interfere in any such way with the application of state compensation legislation to workmen employed upon navigable waters in the performance of non-maritime contracts. On the contrary, it has sought to give the local laws a larger scope than the Supreme Court has been willing to permit. In the situation under discussion both bodies are agreed that local rules are preferable to those of general application. It is doubtful enough whether

12 Even upon this ground the Rohde case has distinet novelty. For in no previous instance had state law been enforced in cascs falling within maritime jurisdiction, where its effect was to abrogate the right to bring suit in admiralty which otherwise would exist. That result is of courze a consequence of the novel feature of workmen's compensation. It is unobjectionable, provided the matter is of no more than local concern and no characteristic features of the general maritime law are involved. 
geographical uniformity should be required in the rights of stevedores. There would be no justification whatever for such a requirement with respect to employment so purely local as Rohde's. If state law is ever to have effect within the maritime jurisdiction, it should be here. Hence the Rohde decision was a necessary limitation upon the uniformity doctrine, and falls into line with the prior development of the maritime law.

The problem remaining for consideration is that of determining more closely just what the circumstances were which made Rohde's rights merely of local concern. The test to be derived from his case has become the critical factor in the rights of the harbor worker who is injured upon the water. The Court's explanation is as follows: ${ }^{43}$

"The contract for constructing 'The Ahala' was non-maritime, and although the incompleted structure upon which the accident occurred was lying in navigable waters, neither Rohde's general employment, nor his activities at the time had any direct relation to navigation or commerce. Thames Towboat Co. v. The Schooner 'Francis McDonald,' 254 U. S. 242. ... The injury was suffered within a State whose positive enactment prescribed an exclusive remedy therefor. And as both parties had accepted and proceeded under the statute by making payments to the Industrial Accident Fund it cannot properly be said that they consciously contracted with each other in contemplation of the general system of maritime law."

There are two distinct factors stated here. The first relates to the type of work Rohde was doing. The state law may govern without undue prejudice to the maritime law, because employment in ship-building has no direct relation to navigation or commerce. But the Court also stresses the fact that both parties had accepted and proceeded under the statute by making payments thereunder. It is difficult to see any significance in the language used, unless the Court meant that the optional nature of the Oregon statute was also a material factor in the decision. The opinion gives little indication of the relative importance of these two circumstances. The only generalization that could safely be made from it is that if the employment is so local in character that it bears only an indirect relation to navigation or commerce and if also the compensation act is of the optional type, then the state law will control. But there is no necessary connection between these two factors. One may be present without the other. Under such circumstances, may the local statute be applied, and if so, is it the type of work or the type of statute that is decisive? The opinion in the Rohde case left the lower courts in much doubt as to these points.

The New York courts were confronted with the problem in

${ }^{13}$ Supra note 38, at 475,42 Sup. Ct. at 158. 
Lahti v. Terry \& Tench Co., Inc.4 There a worlman employed in the construction of a pier was injured while standing upon a floating raft. It is evident that his employment and activities vere as local as Rohde's. But the New York compensation statate was of the compulsory type, no option being given the parties as to its application. Hence if the elective nature of the Oregon statute was an essential factor in the Rohde decision, it would te necessary to decide the Lahti case the other way. The Court of Appeals concluded that the difference in the form of statute must be vital, and that a compulsory act could not be applied to an injury upon navigable water's even where the employment was of a local nature. But its judgment denying compensation was reversed by the United States Supreme Court in a memorandum decision.45 Although the higher court gave no explanation of its decision, the only conclusion to be drawn is that the type of the compensation statute, whether compulsory or elective, is immaterial, and that the local law may be applied in any case where the workman's employment and activities have no direct relation to navigation or commerce. This result is in harmony with the general limitations which the Supreme Court has placed upon the requirement of uniformity. The issue is whether or not the application of local rules would work material prejudice to any characteristic feature of the maritime law, and this depends upon the objective circumstances and not upon the choice of the parties. Nevertheless it is surprising that only a memorandum decision should have been handed down in this case. Whatever the merits, the language used in the Rolhdo opinion left the point involved open to reasonable doubt, and the statements there made as to the acceptance by the parties of the state statute seem to be deprived of significance by the later decision. The desirability of clarifying a confusing situation, coupled with the eminence of the court whose judgment was reversed, would seem to have called for the writing of an opinion..$^{15}$

Another situation exists which is the converse of that presented in the Lahti case. There the work was local and the act compulsory. Suppose on the other hand that the work bears a direct relation to navigation and commerce, as in the case of

240 N. Y. 292, 148 N. E. 527 (1925). For further statement of the views of the New York court, see Danielsen v. Morse Dry Docli \& Repair Co., 235 N. Y. 439, 139 N. E. 567 (1923), cort. denied, 262 U. S. 756, 43 Sup. Ct. 703 (1923).

\&5 State Industrial Board v. Terry \& Tench Co., Ine., 273 U. S. 689, 47 Sup. Ct. 90 (1926). Decisions of state courts to the same effect are: Zahler v. Dept. of Labor and Industries, 125 Wash. 410, 217 Pac. 55 (1929); Los Angeles Shipbuilding \& Dry Dock Co. T. Industrial Accident Commission, 57 Cal. App. 352, 207 Pac. 416 (1922).

* For a discussion of this aspect of the Lahti case see Note (1027) 40 HARv. L. REv. $48 \overline{5}$. 
stevedoring, but the compensation act is of the optional type and the parties elect to come under it. Does the Rohde opinion justify the conclusion that the local statute may be applied? It has been supposed by a few state courts that an affirmative answer should be given. ${ }^{47}$ There is little probability, however, that this view would be approved by the Supreme Court, and the greater number of state courts have held to the contrary. ${ }^{48}$ The Lahti decision indicates that the nature of the employment is the decisive factor. And if characteristic features of the maritime law are involved in the rights of stevedores injured on the water, those features are prejudiced when they are superseded by an exclusive state law, whether the parties have so elected or not. The application of local compensation acts under these conditions would constitute a serious inroad upon the requirement of uniformity, since uniformity could be destroyed with respect to any maritime employment wherever the statute was of the optional type. Certainly the parties cannot by their own choice, with or without state sanction, secure to state tribunals a jurisdiction which it is beyond the power of Congress to bestow.

It is equally unlikely that the requirement of uniformity can be evaded by means of the clause added in 1922 to the workmen's compensation act of New York, ${ }^{40}$ which provides that awards thereunder may be made in respect of injuries subject to admiralty or other federal laws in case the parties waive their admiralty or interstate commerce rights and remedies. ${ }^{\text {.0 }}$

47 Rickert v. Industrial Accident Commission, 122 Ore. 565, 250 Pac. 205 (1927); West v. Kozer, 104 Ore. 94, 206 Pac. 542 (1922); Span v. John Baizley Iron Works, Am. Mar. Cas. 1351 (Pa. Super. 1928); Berry v. M. F. Donovan \& Sons, 120 Me. 457, 115 Atl. 250 (1921); see State v. W. C. Dawson \& Co., 122 Wash. 572, 580, 211 Pac. 724, 726 (1922). But see Zahler v. Dept. of Labor and Industries, supra note 45, at 426, 217 Pac. at 60 .

48 March v. Vulcan Iron Works, 102 N. J. L. 337, 132 Atl. 89 (1926), cert. denied, 271 U. S. 682,46 Sup. Ct. 632; Leszczymski v. Andrew Radel Oyster Co., 102 Conn. 511, 129 Atl. 539 (1925); Lee v. Licking Valley Coal Digger Co., $209 \mathrm{Ky} .780,273$ S. W. 542 (1925); Bell v. Southern Casualty Co., 267 S. W. 531 (Tex. Civ. App. 1924); State v. Duffy, 113 Ohio St. 579,149 N. E. 870 (1925); see also the earlier cases cited in Note (1923) 25 A. L. R. 1029, 1032.

Perhaps the question is foreclosed by Peters v. Veasey, 251 U. S. 121, 40 Sup. Ct. 65 (1919). There it was held that the workmen's compensation law of Louisiana could not be applied to a longshoreman injured on navigable waters. The act was of the elective type, but this feature of the case was not noticed in the opinion, which merely followed the authority of the Jensen case and was of course written prior to the decision in Grant Smith-Porter Co. v. Rohde.

49 N. Y. Laws 1922 , c. $615, \S 113$.

50 See Christensen v. Morse Dry Dock \& Repair Co., 216 App. Div. 274, 214 N. Y. Supp. 732 (2d Dep't 1926), appeal dismissed, 243 N. Y. 587, 154 N. E. 616 (1926). 
The result of this discussion is that the decision in Grant Simith-Porter Co. $v$. Rohde rests to no extent upon the type of compensation statute. Whether or not the local law may be applied to a harbor worker injured upon navigable waters depends solely upon whether his employment and activities have a direct or an indirect relation to navigation and commerce. This is a question which it is not always easy to determine. No more detailed a test can be formulated. The distinction is merely one of degree, and where the line falls can be determined only as it is charted by the decisions of the Supreme Court. Its position may be fixed with a fair degree of clarity by a review of the cases decided up to the present time. Stevedoring of course bears a direct relation to navigation and commerce, as the Jensca and Dawson cases have established. Similarly, in Gicat Lalies Dredge \& Dock Co. v. Kiercjewski ${ }^{\text {s1 }}$ and Gonsalves v. Monse Diry Dock \& Repair Co., ${ }^{52}$ the Supreme Court held that uniformity is required as to the rights of a workman employed under a maritime contract in the repair of a vessel. It seems equally plain that employment under a non-maritime contract, as in the ship-construction involved in the Rolide case, falls on the other side of the line.

The next case in which the Rohde decision was followed by the Supreme Court was Millers' Indeminity Undcrwitcrs 2. Eroud.: Here the employee was a diver who was killed while submerged from a floating barge anchored in a river and engaged in sawing off the timbers of an abandoned set of ways, which had become an obstruction to navigation. It was held that his employment had no direct relation to navigation or commerce and that the state compensation act could apply. The opinion contains no mention of whether the contract here was maritime or nonmaritime, although the point was open to possible doubt. ${ }^{5 i}$ There was, however, no need of discussing the matter. The basis of the Rohde doctrine is not jurisdictional, but it rests upon the absence of undue prejudice to the characteristic features and proper uniformity of the general maritime law. Eren a maritime contract might be primarily of local rather than general concern. Certainly this was so as to the employment of the diver in the Braud case.

In Rosengrant v. Harvard. 5 the injured man was employed as a lumber inspector and checker. At the time of injury he was sitting on a moored vessel tallying lumber, which was being

51261 U. S. 479,43 Sup. Ct. 418 (1923).

52266 U. S. 171, 45 Sup. Ct. 39 (1924).

v3 270 U. S. 59, 46 Sup. Ct. 194 (1926).

54 Cf. De Gaetano v. ITerritt \& Chapman Co., 203 App. Div. 259, 196 N. Y. Supp. 573 (3d Dep't 1922); see also Colonna's Shipyard, Ine. v. Lowe, 22 F. (2d) 813, 844 (E. D. Va. 1927). 
removed from a barge alongside. It was held by the Supreme Court of Alabama that this work, which could just as well have been done on land, was local in character, and that the employment was governed by the state compensation act. This holding was affirmed by the United States Supreme Court in a memorandum decision. In Alaska Packers' Ass'n v. Industrial Accident Commission ${ }^{56}$ the employee was engaged to go to Alaska as a seaman on a fishing vessel and, after arriving at a cannery there, to go ashore and work as directed. He was injured there while standing on the shore endeavoring to push into navigable water a stranded boat. The latter had theretofore been used for taking fish, but the fishing season had ended and the immediate purpose was to float the boat to the dock nearby in order that she might be lifted thereon and stored for the winter. It was contended by counsel that at the time of the injury the man was acting as a seaman. Had this been the fact, it would have been necessary to decide the question discussed earlier in this article as to the status of a seaman injured on land. As the Court viewed the case, however, he was engaged at the time in question not as a seaman, but in land labor in connection with the canning operations. This being so, it is plain, as the Court held, that his activities were merely local in character. Even if the work had been directly concerned with navigation the injury took place on land and the state law would apply under the authority of the Nordenholt case.

The latest of this series of cases to be decided by the Supreme Court is Sultan Railway \& Timber Co. v. Department of Labor and Industries.57 Certain employees were engaged in logging operations, their duties consisting in putting sawlogs into booms, after they had been thrown into a river, so that they could conveniently be towed elsewhere; other men were employed in talsing apart the booms after they had been transported. None of them participated in the actual work of transportation. It was held that such activities bore no more than an incidental relation to navigation and commerce, and that the local law controlled.

These decisions give a general indication of how far state compensation laws may be applied to injuries occurring upon navigable waters. Broadly speaking, the material factors may be reduced to one. Such circumstances as the nationality of the vessel concerned or the residence of her owners appear to be indecisive. Nor does it seem to be important whether or not interstate or foreign commerce is involved. ${ }^{\mathrm{cs}}$ The result depends

5273 U. S. 664, 47 Sup. Ct. 454 (1927), aff'g 213 Ala. 202, 104 So. 409 (1925).

so 48 Sup. Ct. 346 (U. S. 1928).

5348 Sup. Ct. 505 (U. S. 1928).

ss But see Spitzer v. The Annette Rolph, 110 Ore. 461, 474, 223 Pac. 253, 256 (1924). 
solely upon the closeness of the relationship between the employment in question and navigation or commerce in general upon navigable waters. Upon this basis it seems fairly clear that the cases just reviewed have been correctly decided.

Other cases, however, which have not been reviewed by the Supreme Court, have involved more difficulty. And the great variety of circumstances involved in the varying transactions that occur make for many close cases, to which the general test cannot be applied with confidence in the advance of court action.59 This difficulty of application to new cases constitutes a major objection to the Rohde doctrine, as compared with the more natural classification into seamen on the one hand and harbor workers on the other. It is a difficulty which has not arisen in the older situations, in which state laws of other sorts have been applied within maritime jurisdiction. This trouble will be diminished, of course, as the line of demarcation is more closely drawn by future decisions; and the further charting of this line (together with the determination of the status of a seaman injured on land in the course of his employment) constitutes the principal matter remaining to be worked out with regard to the application of state compensation laws to maritime injuries.

\section{THE FEDERAL COMPENSATION ACT}

The requirement of uniformity, as established by the Jcnscir and subsequent cases, has never met with the approval of Congress. In the Acts of 1917 and 1922 that body attempted to control the matter by giving to the state compensation acts a scope larger than that permitted by the Supreme Court. Such power being denied it, only one method remained of securing to maritime workers, beyond the limited field left to the state laws by the Rohde doctrine, the benefits of workmen's compensation. That was of course through the passage of a federal compensation act which should be geographically uniform in its operation. As to the scope of such an act, some choice was left to Congress. The law might be made to apply up to the extreme

59 Cases illustrative of the difficulty encountered by the courts in applying the test established by the Rohde decision are: Zurich Co. v. Industrial Accident Commission, 191 Cal. 770, 218 Pac. 563 (1929), cert. denicd, 208 U. S. 722, 44 Sup. Ct. 230 (1924); Southern Surety Co. v. Crawford, 274 S. W. 280 (Tex. Civ. App. 1925), cert. denied, 270 U. S. 655, 46 Sup. Ct. 253 (1925); City of Oakland v. Industrial Accident Commission, 198 Cal. 27S, 244 Pac. 353 (1926); IIcNamara v. MicHarg-Barton Co., 200 App. Div. 188, 192 N. Y. Supp. 743 (3d Dep't 1922); Jones v. Crescent City Ice IIfg. Co., 162 La. 151, 110 So. 182 (1926); Johnson v. Swonder, 84 Ind. App. 155, 150 N. E. 615 (1926); London Guarantce Co. v. Industrial Accident Commission, 265 Pac. 825 (Cal. 192S); Travelers Insurance Co. v. Bacon, 30 Ga. App. 728,119 S. E. 458 (1929); Beyerle v. Industrial Accident Commission, 75 Cal. App. 19, 241 Pac. $\$ 94$ (1925). . 
limits of admiralty jurisdiction (thus raising the questions discussed earlier in this article as to just what those limits are with respect to workmen's compensation). Or the law might cover only the field within which uniformity is required, leaving to state legislation the fullest permissible scope. In view of the favor with which Congress had previously viewed the application of the state acts in this field, it was to be expected that it should adopt the second alternative. This was done in the passage of the Longshoremen's and Harbor Workers' Compensation Act in 1927. ${ }^{\circ 0}$ Section 3 of this Act, relating to coverage, rends as follows :

"(a) Compensation shall be payable under this chapter in respect of disability or death of an employee, but only if the disability or death results from an injury occurring upon the navigable waters of the United States (including any dry dock) and if recovery for the disability or death through workmen's compensation proceedings may not validly be provided by State law. No compensation shall be payable in respect of the disability or death of-

“(1) A master or member of a crew of any vessel, nor any person engaged by the master to load or unload or repair any small vessel under eighteen tons net; or

"(2) An officer or employee of the United States or any agency thereof or of any State or foreign government, or of any political subdivision thereof.

"(b) No compensation shall be payable if the injury was occasioned solely by the intoxication of the employee or by the willful intention of the employee to injure or kill himself or another."

It seems clear that the provision for the payment of compensation, only if recovery for the disability through workmen's compensation proceedings may not validly be provided by state law, is intended to leave the state acts in full possession of the field open to them under the constitutional decisions of the Supreme Court. Hence the federal Act does not apply to any case within the scope of the Nordenholt and Rohde decisions, and the doctrine of the latter becomes the primary test of its application. The question is not whether the state concerned actually has a compensation law, but whether, if it had, such law could constitutionally be applied. The further limitation of the Act to injuries occurring upon navigable waters adds no more, ${ }^{62}$ since under the Nordenholt case harbor workers injured

${ }^{60} 44$ STAT. 1424 (1927), 33 U. S. C. $\$ \$ 901-950$ (1926). For a discussion of the Act, see (1928) 28 Cor. L. REv. 88.

61 The inclusion within the term "navigable waters" of "any dry dock," although open to theoretical objection so far as docks permanently attached to the land are concerned, is supported by authority. The Robert W. Parsons, 191 U. S. 17, 24 Sup. Ct. 8 (1903); The Anglo-Patagonian, 235 Fed. 92 (C. C. A. 4th, 1916), cert. denied, 242 U. S. 636, 37 Sup. Ct. 10 
on land in the course of maritime employment may validly be subjected to state law. So far as seamen are concerned, they are expressly excluded from the operation of the Act. Workers of this class are left to their rights under the maritime law, together with the right given them by the Jones Act ${ }^{2}$ to maintain at their election an action under the federal Employeis' Liability Act applicable to railway employees.

A clause of doubtful expediency is that excluding from the operation of the Compensation Act "any persons engaged by the master to load or unload any small vessel under 18 tons net." There is nothing in the opinions of the Supreme Court to indicate that the requirement of uniformity, which normally applies to the work of loading or unloading vessels, may be limited according to the size of the craft. Unless some such limitation is to be made, such workers could not be protected by a state compensation act. Being expressly excluded from the federal Act, the benefits of workmen's compensation appear to be wholly denied to them. While the rights given seamen by the Jones Act might perhaps be extended to them, ${ }^{63}$ it is questionable whethex there is sufficient justification for separating them from other harbor workers.

In addition to the provisions of section 3 quoted above, a further clause relating to the scope of the Act is found in subdivision 4 of section 2, where the term "employer" is defined as "an employer any of whose employees are employed in maritime employment, in whole or in part, upon the navigable waters of the United States (including any dry dock)." Generally spealing, employment which is "maritime" will also bear a direct relation to navigation or commerce, and so, if the injury occurs on navigable waters, recovery "through workmen's compensation proceedings may not validly be provided by State law." Hence the scope of the Act as defined by this phrase in section 2 will normally coincide with that fixed by the latter provision contained in section 3. If there is any difference in meaning between the two clauses, however, that in section 2 would appear to be the broader. In any case where the employment bore a direct relation to navigation or commerce, so that state law could not constitutionally be applied, such employment would

(1916) ; Butler v. Robins Dry Dock \& Repair Co., 240 N. Y. 23, 147 N. E. 235 (1925) ; O'Hara's Case, 248 ILass. 31, 142 N. E. $\$ 14$ (1924). Eut “dry dock" does not include a marine railway. Colonna's Shipyard, Ine. v. Lowe, supra note 54 .

6241 STAT. 1007 (1920), 46 U. S. C. $\$ 68 S$ (1926).

63 See International Stevedoring Co. v. Haverty, 272 U. S. 50, 47 Sup. Ct. 19 (1926), holding that longshoremen are "seamen" within the meaning of the Jones Act. Except for persons engaged by the master to lond or unload vessels under 18 tons net, the remedy extendcd to stevcdores by this decision is superseded by the federal Compensation Act. 
have to be "maritime." On the other hand it is possible that some employment might be "maritime" and yet bear a relation to navigation and commerce which would be sufficiently indirect to permit the application of state law. In such event the extent of the two clauses would not be the same and it would be necessary to determine which will control. It seems probable that it was the intention of Congress, in harmony with its previous attitude upon the subject, to leave to the state laws the fullest permissible scope. Therefore the general term "maritime employment" should be limited by the specific requirement of section 3 to the effect that compensation shall be payable only if recovery through workmen's compensation proceedings may not validly be provided by state law. There are as yet no decisions upon the point. ${ }^{64}$

On the whole the interpretation of the Longshoremen's Act should not involve great difficulty. It will be necessary to draw the line between seamen and harbor workers, but this is a familiar distinction in the maritime law. The major problem will be the continued application of the doctrine of Grant SmithPorter Co. $v$ Rohde. ${ }^{65}$ It may seem unfortunate that the test laid down by that case should have been perpetuated by federal legislation. But Congress followed an understandable policy in preserving for local workers such rights as could constitutionally be given them under state compensation acts. And the limits fixed for the Longshoremen's Act are probably as workable as any that Congress could have devised. In fact it does not seem an exaggeration to say that the doctrine of uniformity, as it has been developed by the Supreme Court, has made impossible the drawing of any line of demarcation between state and federal compensation acts, which would be satisfactory in its practical operation. The classification which has the advantage of practical desirability, both in its social consequences and in ease of application, is that into seamen and harbor workers. Fad Statc of Washington v. W. C. Dawson \& C $0^{\circ 6}$ been decided the other way, the most satisfactory solution of the whole problem would have been reached. But such a solution has been denied and local uniformity in the rights of local employees has been sacrificed in order that geographical uniformity might be made secure. And to what end? In a large proportion of cases the only gain to the employer has been that he must now insure under two compensation acts instead of one.

64 For the views of the United States Employees' Compensation Commission, to which the administration of the Act is intrusted, see Longshoromen's Act, Opinion No. 2, Am. MIar. Cas. 1552 (1927); Longshoremon's Act, Opinion No. 30, Am. Mar. Cas. 417 (1928).

65 Supra note 38.

${ }^{63}$ Supra note 18. 